\title{
Flavobacterium gleum, a New Species Found in Human Clinical Specimens
}

\author{
B. HOLMES, ${ }^{1 *}$ R. J. OWEN, ${ }^{1}$ A. G. STEIGERWALT, ${ }^{2}$ AND DON J. BRENNER ${ }^{2}$ \\ National Collection of Type Cultures, Central Public Health Laboratory, London NW9 5HT, England ${ }^{1}$ and Molecular \\ Biology Laboratory, Centers for Disease Control, Atlanta, Georgia $30333^{2}$
}

\begin{abstract}
We propose a new species, Flavobacterium gleum. Each of the 12 strains placed in this new species was examined for 129 characteristics, including reactions in 58 enzyme tests (API ZYM System). These bacteria are rod shaped, aerobic, gram negative, and nonmotile and attack carbohydrates oxidatively. The mean guanine-plus-cytosine content of the deoxyribonucleic acids of six representative strains is $37.6 \pm 1.0$ mol\%. Most strains of the new species were isolated from human clinical specimens; vaginal specimens were a common source. One of the strains included in the new species (strain NCTC 10795) is a reference strain of the unnamed taxon Flavobacterium species group IIb. The type strain is strain F93 $(=$ NCTC 11432).
\end{abstract}

Tatum et al. (23) described various unnamed groups of bacteria, several of which conform to the genus Flavobacterium as redefined by Holmes and Owen (6) and either correspond to existing species or constitute new ones. Group M-4f was shown to correspond to Flavobacterium odoratum (11), and the name Flavobacterium multivorum was given to strains previously assigned to group IIk, biotype 2 (10). Flavobacterium species group IIb, which also corresponds to the revised description of Flavobacterium (6), remains the only unnamed Flavobacterium group of the groups originally described by Tatum et al. (23).

Group IIb was first described by King (14) when she proposed the name Flavobacterium meningosepticum for the taxon which until then had been known as group IIa. King (14) briefly described nine group IIb strains from human clinical sources and noted their similarities to $F$. meningosepticum. Since then various strains identified as group IIb have been isolated from human clinical material and other sources in hospital environments, although the clinical significance of the isolates was generally uncertain (24).

Price and Pickett (21), by performing various numerical taxonomic analyses of phenotypic data on their group IIb strains, found the taxon phenotypically somewhat heterogeneous, although distinct subgroups could not be discerned, and these authors concluded that most of the strains belonged to a single species. Deoxyribonucleic acid (DNA)DNA hybridization data $(18,20)$ have shown that group IIb may comprise two or three separate DNA relatedness groups and thus may contain several species. However, Holmes and Owen (7), referring to an unpublished numerical taxonomic analysis, found little phenotypic data which correlated with the possible DNA relatedness groups within group IIb. The type strain of Flavobacterium balustinum was also included in the cluster of group IIb strains, so the relationship between this species and group IIb was a further consideration (7).

In this study 12 group IIb strains were shown by their phenotypic characteristics, DNA base compositions, and DNA-DNA relatedness levels to constitute a homogeneous taxon which was distinct from other group IIb strains, from

\footnotetext{
* Corresponding author.
}

F. balustinum, and from the other named species of Flavobacterium. For this new taxon the name Flavobacterium gleum is proposed, with strain F93 (= NCTC 11432) as the type strain.

\section{MATERIALS AND METHODS}

Bacterial strains. The 12 bacterial strains studied and the sources from which they were isolated are given in Table 1. The strains were isolated over a period of several years from diverse geographical locations.

Bacteriological investigations. The methods which we used have been described previously (10).

DNA relatedness. The preparation and purification of DNA and the conditions used to determine DNA relatedness by the hydroxyapatite method have been described previously (3). DNA from $F$. gleum strain $F 93^{\mathrm{T}}$ ( $\mathrm{T}=$ type strain) was labeled with ${ }^{32} \mathrm{PO}_{4}$ in vitro (4).

Centrotype. The centrotype was determined by the method of Lapage and Willcox (15).

\section{RESULTS}

Phenotypic characteristics of $\boldsymbol{F}$. gleum. The 12 strains which we studied were strictly aerobic, gram-negative, uniformly staining rods that were 2.0 to $3.0 \mu \mathrm{m}$ long and had parallel sides and rounded ends (Fig. 1). After $24 \mathrm{~h}$ the colonies on nutrient agar were circular, about $2 \mathrm{~mm}$ in diameter, entire, and viscid or butyrous in consistency. A nondiffusible, nonfluorescent bright yellow pigment, which turned red upon addition of $20 \% \mathrm{KOH}$, was produced by all strains. All of the strains also produced a water-soluble dark brown pigment on tyrosine agar. The strains grew at room temperature and at 30 and $37^{\circ} \mathrm{C}$ but failed to grow at $5^{\circ} \mathrm{C}$; nine strains grew at $42^{\circ} \mathrm{C}$. Hemolysis was not present after aerobic growth for $24 \mathrm{~h}$ on $5 \%$ (vol/vol) horse blood agar.

A total of 108 characteristics were common to all strains (either all positive or all negative; see below), and there were 21 characteristics in which one or more of the strains differed (Table 2). Strain F93 ${ }^{\mathrm{T}}$ was the centrotype (there was no median organism). Strains CL344/74, A121/68, and NCTC 10795 were the least typical members of $F$. gleum, and each differed from the other 11 strains in one biochemical characteristic (but not the same one). Nine strains (Table 2) of $F$. gleum produced $\beta$-D-galactosidase as determined by the conventional $o$-nitrophenyl- $\beta$-D-galactopyranoside test, but 
TABLE 1. Strains of Flavobacterium gleum sp. nov. studied

\begin{tabular}{l}
\hline \multicolumn{1}{c}{ Strain } \\
\hline CL344/74 $\ldots \ldots \ldots \ldots \ldots$ Catheter, Birmingham \\
CL542/74 $\ldots \ldots \ldots \ldots \ldots$ Abdominal tap, London \\
CL223/76 $\ldots \ldots \ldots \ldots \ldots$ Dialysis fluid and catheter tip, London \\
A6/68 $(=$ F7 $) \ldots \ldots \ldots \ldots$ High vaginal swab, Rochdale \\
A121/68 $(=$ F61 $) \ldots \ldots \ldots$ High vaginal swab, Liverpool \\
A134/68 $(=$ F66 $) \ldots \ldots \ldots$ Unknown, Rochdale \\
F93 ${ }^{\mathrm{T}}\left(=\right.$ NCTC $\left.11432^{\mathrm{T}}\right) \ldots$ High vaginal swab, London \\
F127 $\ldots \ldots \ldots \ldots \ldots \ldots \ldots$ Vaginal discharge, Rochdale \\
F128 $\ldots \ldots \ldots \ldots \ldots \ldots$ Cerebrospinal fluid, London \\
F129 $(=$ NCTC 11433$) \ldots \ldots$ Wound swab, London \\
F130 $\ldots \ldots \ldots \ldots \ldots$ Peritoneal swab, London \\
NCTC $10795(=3531) \ldots \ldots$ Sputum, South Carolina, United States
\end{tabular}

${ }^{a}$ Geographical locations in the United Kingdom unless otherwise specified.

none of these strains produced $\beta$-D-galactosidase as determined by the API ZYM method (see below).

G $+\mathbf{C}$ content of $\boldsymbol{F}$. gleum DNA. The guanine-plus-cytosine $(G+C)$ contents of the DNAs of six phenotypically representative strains of $F$. gleum have been published previously (19). These values were between 36.0 and $38.5 \mathrm{~mol} \%$, with a mean of $37.6 \mathrm{~mol} \%$ and a standard deviation of $\pm 1.0 \mathrm{~mol} \%$.

DNA relatedness. Labeled DNA from $F$. gleum type strain F93 was 60 to $97 \%$ related (average, $75 \%$ ) to unlabeled DNAs from eight other $F$. gleum strains in hybridization reactions done at $60^{\circ} \mathrm{C}$, a temperature that is close to the

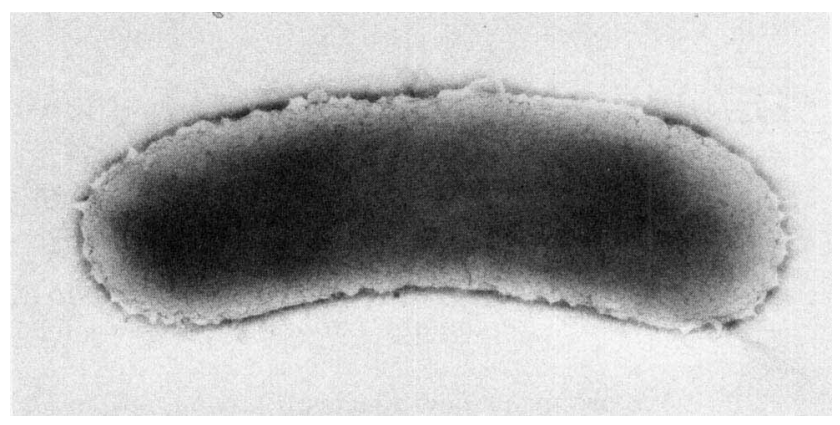

FIG. 1. Electron micrograph of a cell of $F$. gleum type strain NCTC 11432. Cell size is 2.6 by $0.7 \mu \mathrm{m}$.

optimum for DNA reassociation, and 63 to $92 \%$ related (average, $78 \%$ ) to $11 \mathrm{~F}$. gleum strains in reactions done at $75^{\circ} \mathrm{C}$, at which only very closely related DNA sequences can reassociate (Table 3 ). The divergence (percentage of unpaired bases) within related sequences ranged from 1.0 to $3.5 \%$. The level of relatedness of $F$. gleum to strains of $F$. meningosepticum and Flavobacterium breve was 14 to $23 \%$.

\section{DISCUSSION}

Our results indicate that the 12 strains of gram-negative yellow-pigmented bacteria for which we propose the name Flavobacterium gleum (gle'um. Gr. neu. adj. gloion slip-

TABLE 2. Characteristics in which the 12 strains of $F$. gleum differed from each other

\begin{tabular}{|c|c|c|c|}
\hline Characteristic & $\begin{array}{l}\text { No. of } \\
\text { strains } \\
\text { positive }\end{array}$ & $\begin{array}{l}\text { Result of } \\
\text { type strain } \\
\mathrm{F} 93^{\mathrm{T}}\end{array}$ & Strains that gave the less common result \\
\hline Tween 80 hydrolysis & 11 & + & A $121 / 68$ \\
\hline$S$-Benzyl-L-cysteyl- $\beta$-naphthylamide hydrolysis ${ }^{a}$ & 11 & + & NCTC 10795 \\
\hline Deoxyribonuclease production & 10 & + & A121/68, A134/68 \\
\hline Acid from ammonium salt-arabinose & 10 & + & $\mathrm{F} 127, \mathrm{~F} 130$ \\
\hline$\beta-\mathrm{D}-\mathrm{Galactosidase}$ production (ONPG test) ${ }^{b}$ & $9^{c}$ & + & A134/68, F128, NCTC 10795 \\
\hline Growth at $42^{\circ} \mathrm{C}$ & 9 & + & CL542/74, CL223/76, A6/68 \\
\hline Starch hydrolysis & 9 & + & F127, F129, F130 \\
\hline 2-Naphthyl caprylate hydrolysis ${ }^{a, d}$ & 9 & + & CL344/74, CL223/76, F128 \\
\hline Alkali production on Christensen citrate & 8 & + & $\begin{array}{l}\text { CL344/74, CL542/74, A6/68, NCTC } \\
10795\end{array}$ \\
\hline Nitrate reduction & $7^{e}$ & - & A6/68, A121/68, A134/68, F93, F127 \\
\hline Urease production (Christensen medium) & 7 & - & $\begin{array}{l}\text { CL344/74, CL223/76, A6/68, F93 } \\
\text { NCTC } 10795\end{array}$ \\
\hline Tyrosine hydrolysis & 7 & + & A121/68, A134/68, F127, F129, F130 \\
\hline Nitrite reduction & 7 & + & $\mathrm{A} 6 / 68, \mathrm{~A} 121 / 68, \mathrm{~A} 134 / 68, \mathrm{~F} 127, \mathrm{~F} 129$ \\
\hline Oxidative in Hugh-Leifson $\mathrm{O}-\mathrm{F}$ test & 6 & - & $\begin{array}{l}\mathrm{CL} 223 / 76, \mathrm{~A} 121 / 68, \mathrm{~A} 134 / 68, \mathrm{~F}^{2} 3^{\mathrm{T}} \\
\mathrm{F} 127, \mathrm{~F} 129^{f}\end{array}$ \\
\hline Acid from ammonium salt-glycerol & 6 & + & $\begin{array}{l}\mathrm{A} 121 / 68, \mathrm{~A} 134 / 68, \mathrm{~F} 127, \mathrm{~F} 128, \mathrm{~F} 129, \\
\mathrm{~F} 130^{f}\end{array}$ \\
\hline Acid from ammonium salt-xylose & 4 & - & CL344/74, CL542/74, A6/68, A134/68 \\
\hline \multicolumn{4}{|l|}{ Hydrolysis of: } \\
\hline 6-Bromo-2-naphthyl- $\beta$-D-xylopyranoside ${ }^{a}$ & 4 & - & CL344/74, CL 542/74, A121/68, F127 \\
\hline L-Tyrosyl- $\beta$-naphthylamide ${ }^{a}$ & 4 & - & CL344/74, F127, F128, F130 \\
\hline L-Pyrrolidonyl- $\beta$-naphthylamide ${ }^{a}$ & 2 & - & CL344/74, F128 \\
\hline$N$-Carbobenzoxy-L-arginine-4-methoxy- $\beta$-naphthylamide hydrochloride ${ }^{a}$ & 2 & - & F127, F128 \\
\hline Acid from ammonium salt-ethanol & 1 & - & CL344/74 \\
\hline
\end{tabular}

"Tested by using various API ZYM galleries.

${ }^{b}$ ONPG, $o$-Nitrophenyl- $\beta$-D-galactopyranoside.

${ }^{c}$ A positive reaction required 18 to $24 \mathrm{~h}$ of incubation.

${ }^{d}$ Enzyme test included in the standard API ZYM gallery.

${ }^{e}$ These strains could denitrify (i.e., grow anaerobically in the presence of nitrate by using nitrate as a terminal electron acceptor and reducing it to $\mathrm{N}_{2}$ ).

${ }^{f}$ Strains which gave negative results. 
TABLE 3. DNA relatedness among $F$. gleum strains

\begin{tabular}{|c|c|c|c|}
\hline \multirow[b]{2}{*}{ Source of unlabeled DNA } & \multicolumn{3}{|c|}{$\begin{array}{l}{ }^{32} \mathrm{PO}_{4} \text {-labeled DNA from } F \text {. gleum strain } \\
\text { F93 }{ }^{\mathrm{T}}\left(=\text { NCTC } 11432^{\mathrm{T}}\right)\end{array}$} \\
\hline & $\begin{array}{c}\text { Relative } \\
\text { binding index } \\
\text { at } 60^{\circ} \mathrm{C}^{a}\end{array}$ & $\begin{array}{l}\text { Diver- } \\
\text { gence } \\
(\%)^{b}\end{array}$ & $\begin{array}{l}\text { Relative } \\
\text { binding index } \\
\text { at } 75^{\circ} \mathrm{C}\end{array}$ \\
\hline F. gleum $\mathrm{F} 3^{\mathrm{T}}$ & 100 & 0.0 & 100 \\
\hline F. gleum NCTC 10795 & 97 & 3.5 & 82 \\
\hline F. gleum F128 & 92 & 2.0 & 92 \\
\hline F. gleum CL344/74 & 78 & 2.0 & 85 \\
\hline F. gleum CL542/74 & 72 & 2.0 & 82 \\
\hline F. gleum F129 & 71 & 1.5 & 74 \\
\hline F. gleum A134/68 & 65 & 2.0 & 75 \\
\hline$F$. gleum F130 & 64 & 2.0 & 70 \\
\hline F. gleum F127 & 60 & 1.0 & 74 \\
\hline F. gleum CL223/76 & $\mathrm{NT}^{c}$ & NT & 75 \\
\hline F. gleum A121/68 & NT & NT & 66 \\
\hline$F$. gleum A6/68 & NT & NT & 63 \\
\hline $\begin{array}{l}\text { F. meningosepticum } \mathrm{B} 422 \\
(=\mathrm{ATCC} 13254)\end{array}$ & 23 & NT & 18 \\
\hline $\begin{array}{l}\text { F. breve } \mathrm{KC} 1428^{\mathrm{T}}(= \\
\left.\text { NCTC } 11099^{\mathrm{T}}\right)\end{array}$ & 17 & NT & 9 \\
\hline $\begin{array}{l}\text { F. meningosepticum } \mathrm{A} 14^{\mathrm{T}} \\
\left(=\mathrm{ATCC} 13253^{\mathrm{T}}\right)\end{array}$ & 14 & NT & 4 \\
\hline
\end{tabular}

${ }^{a}$ The relative binding index was calculated as follows: (percentage of heterologous DNA bound to hydroxyapatite/percentage of homologous DNA bound to hydroxyapatite) $\times 100$.

${ }^{b}$ Divergence was calculated on the assumption that each $1^{\circ} \mathrm{C}$ decrease in the thermal stability of a heterologous DNA compared with the thermal stability of the homologous DNA duplex was caused by $1 \%$ unpaired bases within the duplex. Divergence was calculated to the nearest $0.5 \%$. All reactions were done at least twice. The values shown are averages. Before normalization to $100 \%$, the percentage of DNA bound to hydroxyapatite in homologous reactions was approximately $40 \%$. The amount of labeled DNA that bound to hydroxyapatite in control reaction mixtures that did not contain unlabeled DNA was 0.6 to $1.7 \%$. These control values were subtracted from all reassociation reaction values before normalization.

${ }^{c}$ NT, Not tested.

pery, sticky; M. L. neu. adj. gleum sticky) constitute a homogeneous taxon. This new species conforms to the definition of Flavobacterium as emended by Holmes and Owen (6). Characteristics that are useful for the practical identification of the new species are shown in Table 4. Pseudomonas paucimobilis is included in Table 4 because this species has biochemical properties that are similar to those of some Flavobacterium species. Table 4 shows that the new species is more similar in phenotypic characteristics to $F$. balustinum, Flavobacterium indoltheticum, and $F$. meningosepticum than to other members of the genus. $F$. gleum differs from $F$. balustinum in producing acid from maltose and trehalose and in hydrolyzing the substrates $\mathrm{L}$ glutamine- $\beta$-naphthylamide hydrochloride and 2-naphthyl- $\alpha$ D-glucopyranoside (API ZYM System; Holmes and Owen, unpublished data). Also, the $\mathrm{G}+\mathrm{C}$ content of the DNA of $F$. balustinum (33.1 mol\% [17]) is slightly lower than the $\mathrm{G}+\mathrm{C}$ contents of $F$, gleum strains. Furthermore, Owen and Holmes (18) have shown by DNA-DNA hybridization that $F$. balustinum is distinct from representatives of group IIb. Similarly, $F$. indoltheticum has a lower $\mathrm{G}+\mathrm{C}$ content $(33.8$ mol\%) than $F$. gleum. In addition, $F$. indoltheticum differs from the new species in failing to produce acid from fructose and trehalose and in growing at $5^{\circ} \mathrm{C}$. In contrast, there are few biochemical tests by which $F$. gleum and $F$. meningosepticum can be distinguished, other than colony pigmenta- tion. The new species forms colonies that are pigmented bright yellow, whereas the colonies of $F$. meningosepticum are pale yellow or even nonpigmented. This pigmentation is the single most useful characteristic for distinguishing these two species.

Although Owen and Lapage (19) suggested that group IIb strains might constitute a subspecies of $F$. meningosepticum, subsequent DNA-DNA hybridization $(18,20)$ showed that group IIb and $F$. meningosepticum are distinct taxa. Owen and Snell (20) showed that three strains (F93 ${ }^{\mathrm{T}}, \mathrm{F} 129$, and NCTC 10795) now placed in $F$. gleum are closely related and could constitute a species. The DNA of strain $\mathrm{F}^{\mathrm{T}}{ }^{\mathrm{T}}$ displayed $100 \%$ relative binding with the DNA of strain NCTC 10795, and the corresponding value for strain F129 was $99 \%$ (20). In the present study DNA relatedness determinations with 11 strains showed that $F$. gleum is a single species that is distinct from $F$. breve and $F$. meningosepticum. The level of relatedness of the type strain to three other $F$. gleum strains was less than the $70 \%$ or more relatedness usually found among strains of a single species. The very low level of sequence divergence among strains (1.0 to 2.0\%) and the high level of relatedness at the stringent $75^{\circ} \mathrm{C}$ incubation temperature ( 70 to $75 \%$ ) attest to the validity of assigning all 12 strains to a single species, $F$. gleum. The identification of additional new species within group IIb and the differentiation of these taxa from $F$. gleum are currently being examined by us because DNA data (18) show that $F$. gleum is distinct from other strains belonging to group IIb.

Few clinical details were available for the strains of $F$. gleum, and the clinical significance of these organisms could not be assessed. The clinical role of Flavobacterium, including group IIb, has been reviewed by von Graevenitz (24), and several reports have drawn attention specifically to the role of group IIb strains in a case of meningitis (2) and in various cases of bacteremia $(5,22)$. The resistance of group IIb strains to a wide range of antimicrobial agents (25) indicates that any infection due to a member of this group could prove difficult to treat. Resistance to antimicrobial agents is a feature that group IIb strains share with most other Flavobacterium species (1, 9-14).

Description of the species and the type strain. The characteristics for which all 12 strains of $F$. gleum gave either positive results or negative results are listed below. The characteristics for which the 12 strains gave different results are listed in Table 2.

Gram-negative, nonsporeforming rods of regular shape with rounded ends. Nonmotile in hanging-drop preparations after overnight growth in nutrient broth incubated at either $37^{\circ} \mathrm{C}$ or room temperature $\left(18\right.$ to $\left.22^{\circ} \mathrm{C}\right)$.

Circular, entire colonies that are viscid or butyrous in consistency develop on nutrient agar, becoming mucoid and translucent after incubation for 5 days. Colonies nonhemolytic on $5 \%(\mathrm{vol} / \mathrm{vol})$ horse blood agar. On nutrient agar, a bright yellow pigment is produced, which is not fluorescent and turns red upon addition of $20 \% \mathrm{KOH}$. A water-soluble brown pigment is produced on tyrosine agar.

Aerobic.

Growth at room temperature and at $37^{\circ} \mathrm{C}$ but not at $5^{\circ} \mathrm{C}$.

Production of catalase and cytochrome oxidase.

Does not tolerate $\mathrm{KCN}$ at a concentration of $0.0075 \%$ (wt/vol).

Hydrolysis of Tween 20.

Production of opalescence on lecithovitellin agar.

Production of indole (Ehrlich reagent); no production of indole (Kovacs reagent).

No production of hydrogen sulfide (lead acetate paper and 
TABLE 4. Characteristics for practical identification and differentiation of $F$. gleum from other Flavobacterium species and from Pseudomonas paucimobilis ${ }^{a}$

\begin{tabular}{|c|c|c|c|c|c|c|c|c|c|}
\hline Test & $\begin{array}{c}F . \text { gleum } \\
\text { (12 strains) }\end{array}$ & $\begin{array}{c}F . \text { balus- } \\
\text { tinum } \\
\text { (1 strain) }\end{array}$ & $\begin{array}{l}\text { F. breve } \\
\text { (7 strains) }\end{array}$ & $\begin{array}{l}\text { F. indol- } \\
\text { theticum } \\
\text { (1 strain) }\end{array}$ & $\begin{array}{l}F . \text { meningo- } \\
\text { septicum } \\
\text { (49 strains) }\end{array}$ & $\begin{array}{c}\text { F. odor- } \\
\text { atum } \\
(28 \text { strains })^{b}\end{array}$ & $\begin{array}{c}F . \text { multi- } \\
\text { vorum } \\
(28 \text { strains })^{c}\end{array}$ & $\begin{array}{c}F_{.} \text {spirit- } \\
\text { ivorum } \\
(13 \text { strains })\end{array}$ & $\begin{array}{c}P . \text { pauci- } \\
\text { mobilis } \\
(29 \text { strains })^{d}\end{array}$ \\
\hline Acid from ASS-glucose $\mathrm{e}^{e}$ & + & + & $6 / 7^{f}$ & + & $42 / 49$ & - & + & + & + \\
\hline Acid from ASS-arabinose & $10 / 12$ & - & - & - & $1 / 49$ & - & + & $3 / 13$ & + \\
\hline Acid from ASS-cellobiose & - & - & - & - & $4 / 49$ & - & + & + & + \\
\hline Acid from ASS-ethanol & $1 / 12$ & + & - & - & $28 / 49$ & - & - & + & $26 / 29$ \\
\hline Acid from ASS-fructose & + & + & - & - & $28 / 49$ & - & + & + & $28 / 29$ \\
\hline Acid from ASS-glycerol & $6 / 12$ & - & - & - & $38 / 49$ & - & $27 / 28$ & + & $6 / 29$ \\
\hline Acid from ASS-lactose & - & - & - & - & $27 / 49$ & - & + & + & + \\
\hline Acid from ASS-maltose & + & - & $6 / 7$ & + & $46 / 49$ & - & + & + & + \\
\hline Acid from ASS-mannitol & - & - & - & - & $31 / 49$ & - & - & + & - \\
\hline Acid from ASS-raffinose & - & - & - & - & - & - & + & + & $28 / 29$ \\
\hline Acid from ASS-salicin & - & - & - & - & - & - & + & + & $26 / 29$ \\
\hline Acid from ASS-sucrose & - & - & - & - & - & - & + & + & + \\
\hline Acid from ASS-trehalose & + & - & - & - & $42 / 49$ & - & + & + & + \\
\hline Acid from ASS-xylose & $4 / 12$ & - & - & - & $3 / 49$ & - & + & + & + \\
\hline Casein digestion & + & + & + & + & + & + & - & - & - \\
\hline Esculin hydrolysis & + & + & - & + & $47 / 49$ & - & + & + & + \\
\hline Growth at $5^{\circ} \mathrm{C}$ & - & - & - & + & $1 / 49$ & $1 / 28$ & - & - & - \\
\hline $\begin{array}{l}\text { Growth on MacConkey } \\
\text { agar }\end{array}$ & + & + & + & + & + & + & + & + & - \\
\hline $\begin{array}{l}\text { Indole production (Ehr- } \\
\text { lich reagent) }\end{array}$ & + & + & + & + & $24 / 49$ & - & - & - & - \\
\hline Nitrite reduction & $7 / 12$ & - & - & - & $18 / 49$ & + & - & - & - \\
\hline $\begin{array}{l}\text { Urease production } \\
\text { (Christensen medium) }\end{array}$ & $7 / 12$ & - & - & - & $16 / 49$ & + & $27 / 28$ & + & - \\
\hline $\begin{array}{l}\beta-\mathrm{D}-\text { Galactosidase pro- } \\
\text { duction (ONPG test) }\end{array}$ & $9 / 12$ & - & - & - & $48 / 49$ & - & + & + & + \\
\hline $\begin{array}{l}\text { Guanine-plus-cytosine } \\
\text { content }(\mathrm{mol} \%)\end{array}$ & $\begin{array}{c}37.6 \pm 1.0 \\
(6)^{h}\end{array}$ & $\begin{array}{c}33.1 \\
(1)\end{array}$ & $\begin{array}{l}32.4 \pm 0.6 \\
\quad(10)\end{array}$ & $\begin{array}{c}33.8 \\
(1)\end{array}$ & $\begin{array}{c}37.0 \pm 0.5 \\
(8)\end{array}$ & $\begin{array}{l}31.4-36.1 \\
(10)\end{array}$ & $\begin{array}{l}39.6 \pm 0.5 \\
\quad(11)\end{array}$ & $\begin{array}{l}41.4 \pm 0.4 \\
(6)\end{array}$ & $\begin{array}{l}65.3 \pm 1.0 \\
(12)\end{array}$ \\
\hline
\end{tabular}

${ }^{a}+$, All strains tested positive; - , all strains tested negative. The phenotypic results for $F$. gleum were from this study, and the phenotypic results for the other taxa were obtained from previous work performed at the National Collection of Type Cultures, as follows: $F$. balustinum, Holmes and Owen, unpublished data; F. breve, reference $12 ; F$. indoltheticum and $F$. meningosepticum, Holmes and Owen, unpublished data; $F$. multivorum, reference $10 ; F$. odoratum, reference $13 ; F$. spiritivorum, reference 9 ; and $P$. paucimobilis, reference 8 . The guanineplus-cytosine values for $F$. gleum were obtained previously (19), and the values for the other taxa were obtained as follows: $F$. balustinum, reference $17 ; F$. breve, reference $17 ; F$. indoltheticum, Holmes and Owen, unpublished data; $F$. meningosepticum, references 19 and $20 ; F$. odoratum, reference $16 ; F$. multivorum, reference $10 ; F$. spiritivorum, reference $9 ;$ and $P$. paucimobilis, reference 8 .

${ }^{b}$ Formerly known as group M-4f $(11,23)$.

' Formerly known as group IIk, biotype $2(10,23)$.

${ }^{d}$ Formerly known as group IIk, biotype $1(8,23)$.

a ASS, Ammonium salt-sugar medium.

${ }^{f}$ Number of strains positive/number of strains tested.

${ }^{g}$ ONPG, $o$-Nitrophenyl- $\beta$-D-galactopyranoside.

${ }^{h}$ Mean \pm standard deviation. The numbers in parentheses are the numbers of strains tested for guanine-plus-cytosine contents.

triple sugar iron agar methods).

Growth on $\beta$-hydroxybutyrate (without production of lipid inclusion granules) and on MacConkey agar, but not on cetrimide agar.

Casein digested.

Hydrolysis of esculin and tributyrin.

No utilization of citrate (Simmons medium) or malonate.

No oxidation of gluconate.

No production of arginine deimidase, arginine deiminase, lysine decarboxylase, or ornithine decarboxylase.

No production of 3-ketolactose.

No reduction of selenite and no deamination of phenylalanine.

Production of phosphatase.

Production of acid in ammonium salt medium under aerobic conditions from glucose, fructose, maltose, and trehalose.

No production of acid in ammonium salt medium under aerobic conditions from adonitol, cellobiose, dulcitol, inosi- tol, lactose, mannitol, raffinose, rhamnose, salicin, sorbitol, or sucrose.

No production of acid from $10 \%(\mathrm{wt} / \mathrm{vol})$ glucose or $10 \%$ (wt/vol) lactose.

No production of gas from glucose in peptone-water medium.

Hydrolysis of the following substrates (using API ZYM galleries): 2-naphthyl phosphate at $\mathrm{pH}$ 8.5; L-leucyl-2naphthylamide; L-valyl-2-naphthylamide; 2-naphthyl phosphate at pH 5.4; naphthol-AS-B1-phosphodiamide; 2-naphthyl- $\alpha$-D-glucopyranoside; 6-bromo-2-naphthyl- $\beta$-Dglucopyranoside; 1-naphthyl- $N$-acetyl- $\beta$-D-glucosaminide; bis-( $p$-nitrophenyl)phosphate; 4-methylumbelliferylcellobiopyranoside; L-phenylalanyl- $\beta$-naphthylamide; L-lysyl- $\beta$ naphthylamide; L-histidyl- $\beta$-naphthylamide; glycyl- $\beta$ naphthylamide; L-aspartyl- $\beta$-naphthylamide; L-arginyl- $\beta$ naphthylamide; L-alanyl- $\beta$-naphthylamide; $\alpha$-L-glutamyl- $\beta$ naphthylamide; DL-methionyl- $\beta$-naphthylamide; glycyl-glycyl- $\beta$-naphthylamide hydrobromide; glycyl-L- 
phenylalanyl- $\beta$-naphthylamide; glycyl-L-prolyl- $\beta$ naphthylamide; L-leucyl-glycyl- $\beta$-naphthylamide; L-seryl-Ltyrosyl- $\beta$-naphthylamide; $\quad$ L-glutamine- $\beta$-naphthylamide hydrochloride; $\alpha$-L-glutamyl- $\beta$-naphthylamide; L-isoleucyl$\beta$-naphthylamide; L-ornithyl- $\beta$-naphthylamide; L-prolyl- $\beta$ naphthylamide hydrochloride; L-seryl- $\beta$-naphthylamide; Lthreonyl- $\beta$-naphthylamide; $\quad$ L-tryptophyl- $\beta$-naphthylamide; $N$-carbobenzoxy-glycyl-glycyl-L-arginine- $\beta$-naphthylamide.

No hydrolysis of the following substrates (using API ZYM galleries): 2-naphthyl butyrate; 2-naphthyl myristate; L-cystyl-2-naphthylamide; $\quad N$-benzoyl-DL-arginine-2-naphthylamide; $N$-glutaryl-phenylalanine-2-naphthylamide; 6-bromo2 -naphthyl- $\alpha$-D-galactopyranoside; 2-naphthyl- $\beta$-Dgalactopyranoside; naphthol-AS-B1- $\beta$-D-glucuronic acid; 6bromo-2-naphthyl- $\alpha$-D-mannopyranoside; 2-naphthyl- $\alpha$-Lfucopyranoside; $p$-nitrophenyl- $\alpha$-D-Xylopyranoside; $p$ nitrophenyl- $\beta$-D-fucopyranoside; $\quad p$-nitrophenyl- $\beta$-Lfucopyranoside; $o$-nitrophenyl- $N$-acetyl- $\alpha$-D-glucosaminide; $p$-nitrophenyl-lactoside; $p$-nitrocathechol-sulfate; 4-methylumbelliferylarabinopyranoside; L-hydroxyprolyl- $\beta$-naphthylamide; $N$-benzoyl-L-leucyl- $\beta$-naphthylamide.

The $\mathrm{G}+\mathrm{C}$ content of the DNA is $37.6 \pm 1.0 \mathrm{~mol} \%$, and the $\mathrm{G}+\mathrm{C}$ content of the DNA of the type strain is $37.0 \mathrm{~mol} \%$, as estimated by the thermal denaturation method.

The following two additional strains of $F$. gleum have been deposited in the National Collection of Type Cultures: group IIb strain $3531(=$ NCTC 10795) and strain F129 $(=$ NCTC 11433).

\section{ACKNOWLEDGMENTS}

We are most grateful to API System S.A. for a supply of ZYM galleries. We also thank T. O. MacAdoo for advising us on the etymology of the new specific epithet, E. Roe for secretarial assistance, the staff of the National Collection of Type Cultures Computer Identification Laboratory for their help, and A. A. Porter for the electron micrograph.

\section{LITERATURE CITED}

1. Altmann, G., and B. Bogokovsky. 1971. In-vitro sensitivity of Flavobacterium meningosepticum to antimicrobial agents. J. Med. Microbiol. 4:296-299.

2. Bagley, D. H., J. C. Alexander, V. J. Gill, R. Dolin, and A. S. Ketcham. 1976. Late Flavobacterium species meningitis after craniofacial exenteration. Arch. Intern. Med. 136:229-231.

3. Brenner, D. J., A. C. McWhorter, J. K. Leete Knutson, and A. G. Steigerwalt. 1982. Escherichia vulneris: a new species of Enterobacteriaceae associated with human wounds. J. Clin. Microbiol. 15:1133-1140.

4. Brenner, D. J., A. G. Steigerwalt, R. E. Weaver, J. E. McDade, J. C. Feeley, and M. Mandel. 1978. Classification of the Legionnaires' disease bacterium: an interim report. Curr. Microbiol. 1:71-75.

5. Center for Disease Control. 1974. Nosocomial Flavobacterium bacteremia in patients with arterial cannulae, p. 17-18. In National Nosocomial Infections Study Quarterly Report, Third and Fourth Quarters, 1973, Center for Disease Control, Atlanta, $\mathrm{Ga}$.

6. Holmes, B., and R. J. Owen. 1979. Proposal that Flavobacterium breve be substituted as the type species of the genus in place of Flavobacterium aquatile and emended description of the genus Flavobacterium: status of the named species of Flavobacterium. Request for an Opinion. Int. J. Syst. Bacteriol. 29:416426.

7. Holmes, B., and R. J. Owen. 1981. Emendation of the genus Flavobacterium and the status of the genus. Developments after the 8th edition of Bergey's Manual, p. 17-26. In H. Reichenbach and O. B. Weeks (ed.), The Flavobacterium-Cytophaga group. Proceedings of the International Symposium on Yellow-Pigmented Gram-Negative Bacteria of the Flavobacterium-Cyto- phaga Group, Braunschweig, July 8 to 11,1980 . Verlag Chemie, Weinheim.

8. Holmes, B., R. J. Owen, A. Evans, H. Malnick, and W. R. Willcox. 1977. Pseudomonas paucimobilis, a new species isolated from human clinical specimens, the hospital environment, and other sources. Int. J. Syst. Bacteriol. 27:133-146.

9. Holmes, B., R. J. Owen, and D. G. Hollis. 1982. Flavobacterium spiritivorum, a new species isolated from human clinical specimens. Int. J. Syst. Bacteriol. 32:157-165.

10. Holmes, B., R. J. Owen, and R. E. Weaver. 1981. Flavobacterium multivorum, a new species isolated from human clinical specimens and previously known as group IIk, biotype 2 . Int. J. Syst. Bacteriol. 31:21-34.

11. Holmes, B., J. J. S. Snell, and S. P. Lapage. 1977. Revised description, from clinical isolates, of Flavobacterium odoratum Stutzer and Kwaschnina 1929, and designation of the neotype strain. Int. J. Syst. Bacteriol. 27:330-336.

12. Holmes, B., J. J. S. Snell, and S. P. Lapage. 1978. Revised description, from clinical strains, of Flavobacterium breve (Lustig) Bergey et al. 1923 and proposal of the neotype strain. Int. J. Syst. Bacteriol. 28:201-208.

13. Holmes, B., J. J. S. Snell, and S. P. Lapage. 1979. Flavobacterium odoratum: a species resistant to a wide range of antimicrobial agents. J. Clin. Pathol. 32:73-77.

14. King, E. O. 1959. Studies on a group of previously unclassified bacteria associated with meningitis in infants. Am. J. Clin. Pathol. 31:241-247.

15. Lapage, S. P., and W. R. Willcox. 1974. A simple method for analyzing binary data. J. Gen. Microbiol, 85:376-380.

16. Owen, R. J., and B. Holmes. 1978. Heterogeneity in the characteristics of deoxyribonucleic acid from Flavobacterium odoratum. FEMS Microbiol. Lett. 4:41-46.

17. Owen, R. J., and B. Holmes. 1980. Differentiation between strains of Flavobacterium breve and allied bacteria by comparisons of deoxyribonucleic acids. Curr. Microbiol. 4:7-11.

18. Owen, R. J., and B. Holmes. 1981. Identification and classification of Flavobacterium species from clinical sources, p. 39-50. In $\mathrm{H}$. Reichenbach and O. B. Weeks (ed.), The Flavobacterium-Cytophaga group. Proceedings of the International Symposium on Yellow-Pigmented Gram-Negative Bacteria of the Flavobacterium-Cytophaga Group, Braunschweig, July 8 to 11, 1980. Verlag Chemie, Weinheim.

19. Owen, R. J., and S. P. Lapage. 1974. A comparison of strains of King's group IIb of Flavobacterium with Flavobacterium meningosepticum. Antonie van Leeuwenhoek J. Microbiol. Serol. 40:255-264.

20. Owen, R. J., and J. J. S. Snell. 1976. Deoxyribonucleic acid reassociation in the classification of flavobacteria. J. Gen. Microbiol. 93:89-102.

21. Price, K. W., and M. J. Pickett. 1981. Studies of clinical isolates of flavobacteria, p. 63-77. In H. Reichenbach and O. B. Weeks (ed.), The Flavobacterium-Cytophaga group. Proceedings of the International Symposium on Yellow-Pigmented Gram-Negative Bacteria of the Flavobacterium-Cytophaga Group, Braunschweig, July 8 to 11,1980 . Verlag Chemie, Weinheim.

22. Stamm, W. E., J. J. Colella, R. L. Anderson, and R. E. Dixon. 1975. Indwelling arterial catheters as a source of nosocomial bacteremia: an outbreak caused by Flavobacterium species. N. Engl. J. Med. 292:1099-1102.

23. Tatum, H. W., W. H. Ewing, and R. E. Weaver. 1974. Miscellaneous gram-negative bacteria, p. 270-294. In E. H. Lennette, E. H. Spaulding, and J. P. Truant (ed.), Manual of clinical microbiology, 2nd ed. American Society for Microbiology, Washington, D.C

24. Von Graevenitz, A. 1981. Clinical significance and antimicrobial susceptibility of flavobacteria, p. 153-164. In $\mathrm{H}$. Reichenbach and O. B. Weeks (ed.), The Flavobacterium-Cytophaga group. Proceedings of the International Symposium on Yellow-Pigmented Gram-Negative Bacteria of the Flavobacterium-Cytophaga Group, Braunschweig, July 8 to 11,1980 . Verlag Chemie, Weinheim.

25. Von Graevenitz, A., and M. Grehn. 1977. Susceptibility studies on Flavobacterium II-b. FEMS Microbiol. Lett. 2:289-292. 